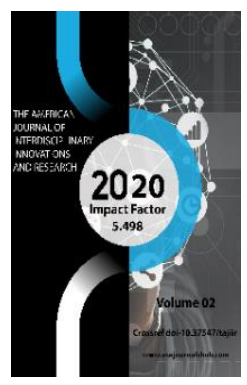

\title{
Ects Credit-Module System In The Universities Of The Republic Of Uzbekistan: Basic Concepts And Rules
}

\author{
Zarina Dadajonovna Boytemirova \\ Doctor Of Philosophy In Philosophy (PhD), Associate Professor Of The Department Of \\ National Philosophy, Fundamentals Of Spirituality And Higher Education Of The Faculty Of \\ History Kokand State Pedagogical Institute, Kokand, Uzbekistan
}

Copyright: Original content from this work may be used under the terms of the creative commons attributes 4.0 licence.

\section{ABSTRACT}

In the article issues such as the essence of the credit-module system of education, how it works, and how the credit - module system arose on the basis of conditions and needs are addressed. What this system gives us and its advantages from the current education management system has been revealed. It is established that training programs should be created in the credit-module system and what other work should be done to study the credit-module system.

\section{KEYWORDS}

Unit of measurement of credit education reading load in credit-module system, results of reading in credit-module system, audience and independent hours in credit-module system, definition of credit and module concepts.

\section{INTRODUCTION}

The current state of development of higher education in Uzbekistan is focused on the European educational and scientific space, characterized by modernization and reforms. This process requires a step-by-step creditmodule system for changing educational programs, forms and methods of training, monitoring and improving the quality of education in accordance with the ECTS (European credit transfer and accumulation system). In this system, education has its own characteristics of elegance, is based on 
national culture and values, and does not harm the national characteristics of the education system. Its goal is to improve the quality of education, accelerate the educational process, update and improve the structure of the teaching staff, bring the staff and students, as well as teaching methods to a higher level. [5]

According to the "Concept for the development of the higher education system of the Republic of Uzbekistan until 2030" approved by the decree of the President of the Republic of Uzbekistan on October 8, 2019 year 85 percent of the country's universities are planned to be gradually transferred to the credit-modular system.[1]

As an experiment, from the 2018-2019 academic year, the Musa al-Khwarizmi Tashkent University of Information Technologies [2] and the Tashkent law University switched to the education system in accordance with ECTS. From the 2020-2021 academic year, among other universities, the credit system of training was started at the Mukimi KSPI.

Based on this, the issue of analyzing the educational process based on the use of credit units-credits, analysis of curricula, disciplines, elective subjects, criteria for evaluating knowledge, the transition from the rating system of assessment to a point-credit system, etc. is relevant.

\section{MAIN PART}

The credit-modular system is the process of organizing education. it is an assessment model based on a combination of modular learning technologies and credit measurement. Conducting it as a whole is a multi-faceted and complex system process. In principle, the credit module attaches great importance to two main issues: ensuring independent work of students, assessment of students' knowledge based on rating assessment.

ECTS credit-module system is built on certain principles. They are as follows:

1) Organization of student oriented education (student-centered education).

2) Achieving transparency in education (transparent education).

3) Increase flexibility in education (improving flexibility).

4) Student mobility (improving student mobility).

Student-oriented education it would be correct to say the opposite of teacher-oriented education. In this system, education requires an approach from the point of view of students, not from the point of view of the institution or teachers controlling it. While universities, the organizations and teachers that control them, are the organizers of educational processes, they basically act as coordinators, that is, educational programs, in particular what the student should learn, how much, in what way students ' interests, needs, expertise and labor market requirements are formulated with in-depth analysis, that is, depending on the "bottom up" (bottom up). In the credit system, again, the teacher is not regarded as the only source of knowledge. Students are actively involved in educational processes. The educational system is directed at the formation of independent thinking in students, sharing their knowledge with others, the potential for making decisions for themselves.

The main functions of the credit module system are recognized as follows:

- Organization of the educational process based on modules; 
- Unified scientific, course (credit) assessment;

- Assessment of students' knowledge based on the rating score;

- Create an opportunity for students to create their own curriculum on an individual basis;

- Increasing the share of independent learning in the educational process;

- Convenience of educational programs.

Tasks and functions of the credit module system:

- improve the quality of education, speed up the learning process, update and improve the structure of teaching activities; bring training, training of future teachers and students, as well as teaching methods to a higher level.

- full provision of the educational process with all necessary methodological tools, preparation of materials in printed and electronic forms, credit-modular construction of the educational process, use of credit points to assess the quality of education, personal participation in the formation of the personality of each student, a curriculum based on a large freedom of choice of subjects, involvement of academic consultants (Tutors) to participate in the learning process;

- adaptation of all educational areas of the bachelor's degree using the ESTS (European credit transfer system) types of work and activities in the educational process, developed on the basis of state educational standards. The evaluation scale adopted in the educational system EST ("excellent", "good", "satisfactory", "unsatisfactory" or "credit", "no credit") and, based on international experience, is the estimate of the average scaled score, the credits the student with a positive assessment of his academic work.[3]

The main advantages of the credit-modular approach are: compactness (forming a block of several disciplines for a specific purpose), term - calendar module, the composition of each academic science, components-modules of Sciences, acceleration of independent work of students due to rational organization and constant monitoring, regularity and objectivity of evaluation of teachers and students.

Let us focus on the concepts of the creditmodular system.

A module is a part of a curriculum that studies several subjects and courses. This is a combination of several disciplines (courses) aimed at developing students ' specific knowledge and skills that have the potential to conduct analytical and logical observation. The teacher organizes the learning process, conducts live, video and audio lectures, coordinates and controls the student's activities. A student independently studies the subject and performs these tasks.

According to international experience, the educational process in the credit module system will consist of 6-7 modules in each semester. The subjects concentrated in the module are easily formed based on complexity, theoretical and methodological subjects depending on practical subjects, and logically based on complementary printing. To form a student as a specialist, it is necessary not only to have knowledge, but also to be able to process it and put it into practice.

Modular training programs are developed according to a special scheme and include:

- Full disclosure of educational goals and objectives; 
- Requirements for the student's qualifications, which must begin and increase after the course ends;

- A summary of each subject included in the module (syllabus), that is, the topics of lectures, the plan of seminars and practical classes, tasks designed to assess the independence of learning;;

- Brief description of the learning process: method and means of learning; consists of methods and forms of knowledge assessment.

The module is based on a rating system for evaluating students ' knowledge, qualifications and skills in the training system. In it, the entire student's educational activities, that is, the knowledge acquired outside of the classroom and the audience, are evaluated using a point score.[3]

Credit (credit) is a unit of measurement of the academic load (time) spent by a student on studying and mastering subjects in a particular direction or program of study (course). Credit is a minimum measure of time that is set by a student's regulatory act, usually allocated for a week in the classroom and for independent study. Credit is given to a student after successfully passing the final exam, completing tasks set for a specific subject.

Each student must accumulate credits in order to have a diploma in the chosen field and specialty in the future. The accumulated credit will continue to serve the student throughout their life to improve their skills or obtain additional higher education. In economic terms, the accumulated credit becomes an academic "asset" of the student.

Credit technology gives education recipients the right to choose elective subjects included in the working curriculum, so they are directly involved in the formation of an individual curriculum. Students are given a choice of not only subjects, but they can also choose a Professor and a teacher. It is considered positive that students are given the opportunity to choose subjects. This is also considered as an indicator of the specific value of evaluating training processes.

Another important aspect of the transition to a credit-module system is the penetration of selection sciences into this curriculum. According to him, in the first years of his studies, after mastering the basic, generalmilitary disciplines related to the field and gaining general knowledge in the field, they will now have the opportunity to choose special subjects related to the field of study from their own interests. This process offers students a selection $R$ reflection of subjects and detailed information about them that can be offered during the academic year. And the students choose the subjects they are interested in based on this list of it and data. This process allows each student to formulate his or her own bachelor's or Master's degree program in a certain sense. That is, in the group 50 if a student dies $b$, each of them read their own read $\mathrm{K}$ ogre their own behavioral will have programs.[4]

\section{RESULTS AND DISCUSSIONS}

1) In the universities operating on the basis of ECTS and other similar credit - module system in the country, it is recommended that the number of credits that the student must accumulate in order to obtain each stage of Higher Education (Bachelor's, master's degree) be determined by law or legislative acts. This order serves to prevent various abuses (the emergence of short-term baccalaureate, master's degree programs) in the field of higher education 
of the country, where the tobo ra is being liberalized.

2) It is recommended that the scope of the reading load hours attached to each ECTS credit be determined by law or statutory acts. According to the principles of ECTS, this circle is $25-30$ hours.

3) It is recommended that each institution should adopt its own rules on the practice of credit - module system and transparently communicate them to the teachers, students and other interested parties of the institution, which should be established by law or statutory acts.

4) It is recommended to reform the current evaluation system , criteria and scale used in the OTMs and bring them closer to the most advanced evaluation systems in the world. Due to the fact that the number of positive assessments in the current assessment system is quite limited, the assessments do not adequately reflect the differences in the knowledge and potential of the students. For example, in the current assessment scale there are 3 positive assessments $(3,4,5)$, while in the ECTS system there are 5 positive assessments and in the American assessment system there are 12 positive assessments. Kuchaytiradi these big differences in the evaluation practices are likely to be uncertainties and errors in ba-xolar mining.

5) Transition to the credit-module system it is recommended to revise the current legislation, legislation, decisions and regulations of the Ministry of Higher Education with the relevant ati and to introduce relevant amendments to them.

\section{CONCLUSION}

- Her an OT operating in the credit-module system is recommended to determine the reading results of each of its training programs (Bachelor's, master's), to develop the program directory and to place them transparently on the head ida's Web page every academic year. The main purpose of this material preparation in Zero ECTS credit - module system is to bring them to the attention of the students.

- It is recommended to approach the university not only in terms of the development of its curriculum, the results of its study, but also in terms of the point of view of what we want to teach the students, but also in terms of what the students want from us to place and what they need to know and be able to That is, the nouns should ask their predecessors not "what we want to give to the students and what we have given", but "what the students want to receive from us and what they have received". Because what the OTMs give to the student is what the students want, it may not be what they need.

- It is recommended that each OT develop internal rules covering the most basic aspects of the credit-module system and place them on its own web page. It is desirable that the rules of the creditmodule system cover the following main issues: (a) the amount of hours of study load attached to each loan ; $(B)$ the ratio of the audience and independent hours in IT ; (c) the amount of minimum credits that can be distributed to each module; (D) the amount of minimum credits required to pass the student; (e) rules on in which cases the student must re-take the subject ; (j) the maximum time that the student must finish his / her studies; ( $z$ ) the list of compulsory subjects that must be taken in each course according to each educational program. 
- Prepare a science program "syllabus" on each subject and put an outline on its most necessary parts. It is recommended that science programs be submitted to the student no later than 1 week after the start of study by the internal rules of the University.

- It is recommended that each university develop its own rules of coding in such a way that the disciplines and modules in its curriculum contain relevant information and KOD encode the subjects in the appropriate order on the basis of.

- To have an online platform that manages each ATM credit-module system (student registration, record and send assessments, store relevant information).

- Expansion of the scope of competitive Sciences in the curriculum, especially in Higher courses. Talov Sciences should be disciplines related to the professional sphere, directing the formation of special knowledge and skills.

- To organize the position of academic consultant, which advises students in the formation of their own training programs.

- Training on the mechanism and requirements of credit-module system performance for newly accepted students and teachers.

Recommendations for teachers: the results of reading of each subject that the teachers themselves teach it is recommended that they be identified in advance and explain them to students at the beginning of the semester. Bunda main emphasis is placed on the question of what the student knows, understands and can do in the expert sitat as a result of it at the end of science. The reading loads of science will focus on achieving exactly the same reading results as the students. And the method and norms of evaluation of science will be aimed at checking whether the students have achieved exactly the same reading results.

\section{REFERENCES}

1. Decree President of Uzbekistan № DP5847: Concept of development of the higher education system of the Republic of Uzbekistan until 2030/ https://lex.uz/ru/docs/4545887

2. Resolution of Cabinet of ministers of the Republic of Uzbekistan on measures to radically improve the system of personnel training and improve its efficiency at the tashkent university of information technologies named after Muhammad AlKhwarizmi https://lex.uz/docs/3833195

3. Credit-modular system of ECTS in higher educational institutions of the Republic of Uzbekistan: Basic concepts and rules / Vohid Urinov University of new Brunswick, Canadian University faculty of law. Tashkent: 2020

4. Smolyaninova A. G., Dostovalova E. V., Saveleva O. A. / Organization of the educational process of bachelors / masters of pedagogy in the modular credit-rating system of education./Monograph. Siberian Federal University, Russian Federation. Krasnoyarsk, SFU 2009

5. X.A.Ustadjalilova,M.S.Zakirova./Sovershen stvovanie sovremennogo neprerbvnogo obrazovaniya $v$ Respublike Uzbekistan./Education as a factor in the development of intellectual and moral potential of the individual: materials of the VIII Intern.scientific Conf./ Saint Petersburg, 2018, p. 42

6. https://kun.uz/news/2020/07/22/ in highereducation-credit-module-coming-flowyear-students-what-are-waiting 